\title{
Further Discussion on the Spirit of Rule of Law
}

\author{
Xia Zhang \\ College of Marxism \\ Yunnan Normal University \\ Kunming, China
}

\begin{abstract}
Before the discussion of rule of law, firstly, we should understand the concept of law, which has relatively clear definition in academic circles. In general, the law is a kind of norm or normative system which is formulated or approved by the state, and guaranteed and enforced by coercive force of the state, and manifested in the form of rights and obligations. ${ }^{1}$ Similarly, we should first understand what the rule of law is before we learn about some legal terms, such as the idea, the mentality, the consciousness and the spirit of rule of law. The East and the West have different understanding about the concept of rule of law. If we can clarify the historical origin of the rule of law and related concepts, it will help our theory construction on the rule of law.
\end{abstract}

Keywords-rule of law; the spirit of rule of law; construction of rule of law

\section{INTRODUCTION}

The concept of rule of law usually includes some subordinate concepts, such as regime of law, governed by the law, ruling by law, governing with law. The difference between these concepts is that their implicit subjects are people, laws and rulers, however, the understanding of these implicit subjects is the key to learn the true meaning of rule of law, which will lead to different understanding about rule of law. But the object of "rule of law" is always the state no matter what kind of understanding is. We generally believe that all "ruling by god", "rule of man" and "rule of law" dominate in different stages of human history. With the enlightenment of humanism and the rapid development of science and technology, the "ruling by god" has gradually stepped down from the stage of history. In modern society, the "rule of law" certainly represents the general trend of concept of governance of modern states, however, the countries in different historical environments has various understanding on the concept of "rule of law", especially, the concept of "rule of law" in academic circles is confusing after being influenced by "rule of man" for thousands of years. Therefore, under the circumstances that the foundation of the rule of law is absent, the concept of "rule of law" in China we discuss can not be completely separated from the "rule of man".

\section{THE UNDERSTANDING FOR THE CONCEPT OF RULE OF LAW BETWEEN CHINA AND THE WEST}

It is universally accepted by scholars that the distinction between rule of law and rule of man lies in: rule of man refers to the rule of a privileged man; rule of law is the regime of law and the law itself is the subject of rule of law; the governing conception advocated by Chinese Confucian school that rule by rites and rule of virtue means that the gentleman uses his good and honest virtue to educate people is a typical rule of man. Guan Zhong, the pioneer of Legalists in ancient China, once put forward that "the monarch and his subjects no matter how great and small they are complying with the law will be the great order", that is, the fall and rise of the state will not only rely on the monarch but the governing conception whether the monarch strictly complies with the legal system, however, the "rule of law", proposed by Han Feizi who epitomized almost all legalisms in ancient China, is designed around the autocratic monarchy and runs counter to the connotation of democracy and rule of law in modern China. "Limited by the scope of monarchism, Legalists do not require (at least they do not make it explicit) to establish a just judicial system including judgment, hearing, rule of evidence and due procedure, or Chinese Legalists do not care about "natural justice (substantial justice)' in fact." 2 After the fall of the Qin Dynasty, the thought of "rule of law" of Han Feizi was abandoned quickly, and Chinese Legalists have no substantial advancement after Han Feizi. "Running the country according to law" of Chinese Legalism is not the concept of the rule of law that embodies the spirit of democracy, but the law as a ruling tool under the autocratic system. Both "rule of man" of Confucianism and "rule of law" of Legalism belong to governmentality. Advocating rule of law under the autocratic system, in fact, is to use "people" to promote "severe law". 3

Meanwhile, in the ancient western countries, there was a fierce debate between the rule of law and the rule of man, especially in the origin of the spirit of the rule of law in ancient Greek. This debate was conducted about the role of law and sage in state-run. Plato advocated the concept of governing a state by sage with the style of "philosopher king", coming from Utopia written in the prime of Plato. However, after witnessing the pursuit for "philosopher king" turning to dust and ashes, Plato elaborated the pursuit for "rule of law" in his The Law and put forward that "when the law is subject to other authority and it has nothing to do with itself, I think the collapse of the country is not far away. But if the law is the master of the government and the government is its servant, then the situation is full of hope that people can enjoy all the benefits that the gods give to the city."; however, Aristotle criticized the early theory proposed by his teacher and explicitly put forward that "the rule of law should excel rule of a person", and he said "if the requirements are ruled by the law, that is, the requirements are governed by gods and reason; if the requirements are ruled by individual, it is tantamount to open the door to a dangerous person. Because the human's lust 
is like a beast, although the supreme sage will be mislead by the strong emotion, only the law can have reason and exemptions." 4

We can see that both in the West and the East in ancient times, the debate between "rule of law" and "rule of man" has an factor that can not be excluded, that is, "man". "Law is made by man. How can this Law govern human beings?" ${ }^{5}$ The western world that has dense tradition of Abraham monotheism can easily personify the law as the dominator. After Plato, Aristotle and the representatives of other schools, like the Stoics and Cynic school, have drastic collision of ideas, meanwhile, they inherit the grand law language and rich law practice of the Romans, with the legal system centered on civil law, the jurisprudence thinking centered on civil thinking and the legal theme based on rights and obligations; due to the absence of authoritarianism, the civil law (citizen of Roman) and the jus gentium (non-citizen of Roman) in Roman republican did not become the criminal law tools of autocratic monarchy like China, India, Islamic Region. Centered on the concept of private right, these laws constructed the thought and logic of civil law and made the rights and obligations become the concept of Roman law which European democratic movement pursued and strengthened from the Renaissance to Enlightenment.

The most important is that the theological tradition of monotheism (mainly Christian, Catholicism and Judaism) endowed the western world with strong spirit of contract. We know that Judaism is the originator of all Abraham monotheisms. Mose carved the "Ten Commandments" on the slab-stone, which marked the birth of Judaism, however, the legend itself of "Ten Commandments of Mose" was the contract between Mose and God at the top of Sinai mountains, and Mose brought the slab-stone down the mountain and told his clansmen to abide by these contracts. According to theological creeds, the world itself is governed by the rules, and the benevolent God is in charge of a world governed by law and puts the shoe on the right foot. Therefore, the relationship between people, including the religious world and the secular world, should be defined on the basis of the justice of law and the law based on justice. Based on this theological thought and due to the political reality of European secession caused by national state and feudalism, under the circumstance that magisterium and royalty kept balance with mutual compromise in Middle Ages, both the magisterium and royalty recognized that the law was higher than the two and they got along with each other. ${ }^{6}$ Therefore, we can see that although before Renaissance Movement, the western mainstream ideology had endowed the rule of law with many meanings and the concept was widely recognized and enjoyed popular support, and this kind of situation never appeared in ancient China.

Based on the spirit of rule of law of ancient Greek, the legal heritage of Romans and the theological tradition of monotheism, modern western countries have formed relatively mature concept of rule of law. Take the concept of rule of law of the United Nations for example, "rule of law refers to a governance principle. Under this principle, all individuals, institutions and units, public and private enterprise, including the state itself, are responsible for the law. The law is promulgated publicly, implemented equally and arbitrated independently, and complies with international human rights norms and standards. Besides, it requires to take measures to adhere to the following principles, namely the supremacy of law, all people are equal before the law, being responsible for law, fairness of applicable law, separation of powers, participative decision making and the certainty of the law, and avoiding arbitrary, transparency of procedure and administration of justice."

\section{CONNOTATION AND DENOTATION OF CONCEPT OF SPIRIT OF RULE OF LAW}

China has always taken the rule of law as an important content of strategy of running a state, but we must realize that the spirit of rule of law is not an empty and universal concept. The connotation and denotation of the spirit of rule of law have various formal elements in different regions, age and cultural background. The Declaration of Independence of America in 1776 declared seriously that "we believe that the following truths are self-evident. All men are created equal, and the Creator endows them with several rights, including the right to life, to liberty and the pursuit of happiness. The Article One of Declaration of the Rights of Man and of the Citizen in the French revolution in 1789 is that men are born and remain free and equal in rights. As we can see that both the two revolutionary historical documents show the most basic connotation in modern spirit of rule of law that "all people are equal before the law". However, the most basic connotation of rule of law has not been implemented in the actual administration, for example, Paragraph Two of Article One of U.S. Constitution in 1787 stipulated that representatives and direct taxes shall be apportioned among the several states which may be included within this union, according to their respective numbers, which shall be determined by adding to the whole number of free persons, including those bound to service for a term of years, and excluding Indians not taxed, three fifths of all other Persons. However, the U.S. Constitution in 1787 did not radically implement the voting right of woman, black people and other ethnic minorities, although it acquiesced in the existence of slavery, the most basic spirit of rule of law that "all people are equal before the law" in modern America also becomes a mere scrap of paper.

27 amendments have been adopted since the implementation of U.S. Constitution in 1789, among which, Article 13 in 1865 stipulated that "neither slavery nor involuntary servitude, except as a punishment for crime whereof the party shall have been duly convicted, shall exist within the United States, or any place subject to their jurisdiction." Paragraph One of 14th Amendment in 1868 stipulated that "all persons born or naturalized in the United States, and subject to the jurisdiction thereof, are citizens of the United States and of the State wherein they reside. No State shall make or enforce any law which shall abridge the privileges or immunities of citizens of the United States; nor shall any State deprive any person of life, liberty, or property, without due process of law; nor deny to any person within its jurisdiction the equal protection of the laws." The 15th Amendment of the U.S. Constitution in 1870 stipulated that "the right of citizens of the United States to vote shall not be 
denied or abridged by the United States or by any State on account of race, color, or previous condition of servitude." The 19th Amendment of the U.S. Constitution in 1920 stipulated that "the right of citizens of the United States to vote shall not be denied or abridged by the United States or by any State on account of sex." The 26th Amendment of the U.S. Constitution in 1970 stipulated that "the right of citizens of the United States, who are eighteen years of age or older, to vote shall not be denied or abridged by the United States or by any State on account of age."

From the above amendments, we can see that the rule of law in the United States is not accomplished in an action. The basic concepts that "all people are equal before the law" and "the same rights are enjoyed by different races, colors, and sexes" which seem unusual are constantly added to the spirit of rule of law of the United States through American Civil War, Civil Rights Movement and Feminist Movement in the eighteenth and nineteenth century. It is precisely because the connotation of the spirit of rule of law has various formal elements in different regions, times and cultural backgrounds, so the connotation of the spirit of rule of law is varied. From the literal meaning, we can analyze that the connotation of the spirit of rule of law roughly has three meanings: the first is the ideal and value orientation of good law and governance, that is, the spirit of good law and governance. The second is that the dominator applies the spirit of rule of law to govern the country whether it is good law and governance or bad law and governance. The third is all the awareness or ideologies about the rule of law.7 The three meanings have corresponding signifies in different contexts from narrow sense to broad sense; as pointed out by Aristotle that "the rule of law should include twofold connotations: the laws that have been established receive universal obedience, and the law that everyone obeys should be a good law."8 Wang Anshi, politician in Song dynasty, said that "make good laws in the world, the world is ruled; make good laws in a country, the country is governed". All these can be understood as "the ideal and value orientation of good law and governance, that is, the spirit of good law and governance."

Therefore, we can say that "the ideal and value orientation of good law and governance, that is, the spirit of good law and governance" that better conforms to the connotation of the spirit of the rule of law under the contemporary context. About the specific elements of the connotation of the spirit of the rule of law, Chinese scholars have made many expositions. Li Deshun, professor of China University of Political Science and Law, believes that the spirit of the rule of law is actually a sense of public rule. The so-called public rule is to give concrete analysis and definition to everyone's rights and responsibilities in specific matters, respect and protect everyone's rights, and also determine everyone's responsibilities that they should bear.9 Wang Chunhui, the researcher of enterprise and corporation law research center of Peking University, thinks that the spirit of the rule of law should contain five basic elements: first, the law must represent the will of the overwhelming majority of the people, and must be established on the basis of legislation for the people; second, determine the national structure of the supremacy of constitution and law; third, establish a legal culture that all people are equal before the law; fourth, the fundamental objective of law is to protect the civil rights and achieve justice; fifth, the power of the government should be restricted. Li Buyun, the research of Chinese Academy of Social Sciences, believes that the spirit of the socialist rule of law should at least contain the following six aspects: the first is popular sovereignty, the second is protection of human rights, the third is restriction of powers, the fourth is isonomy, the fifth is the justice of procedure and the sixth is the supremacy of law.10 Zhang Xianwen, professor of Jilin University, thinks that the spirit of the rule of law integrates " the spirit of good law, democratic spirit, human-rights spirit, the spirit of justice, rational spirit and harmonious spirit."11 Li Lin, the research of Chinese Academy of Social Sciences, generalizes the spirit of the rule of law as popular sovereignty, the supremacy of constitutional law, respecting and protecting human rights, authority primacy, law-based administration of government, judicial justice, supervision and restriction of public power. 12 Hao Yaowu and Sun Changchun believe that the core of the spirit of the rule of law is to maintain the legal dignity, protect the civic rights, and maintain the social justice. 13

There are many various statements on the extension of the spirit of the rule of law. The extension of the spirit of the rule of law is the object scope determined and each aspect included by the spirit of the rule of law. $14 \mathrm{We}$ can understand the extension of the spirit of the rule of law as the principle of rule of law that the rule of law should abide by in the concrete implementation. The principle of rule of law is the application of the spirit of the rule of law in the legal system and legal order. In the basic sense, the principle of rule of law is designed to achieve the basic principles for the rule of law through the legal system, and the principle of rule of law is also the concentrated reflection of the spirit of rule of law. Raz, professor of philosophy of right in Oxford and the distinguished scholar in the field of contemporary law and politics, has put forward eight principles of rule of law in The Authority of Law: Essays on Law and Morality: this law is not retroactive and should be open and clear; the law should be relatively stable; the formulation of the special law should be guided by open, stable and clear general rules; ensure the judicial independence; comply with the principles of natural justice; the court holds the right to review the implementation of parliament and administrative legislation; the court should be easy to approach; the anticrime organs must not abuse the law when exercising the discretionary power. Newman, German scholar, has summed up three principles of rule of law: the universality or generality of the law; the non-retroactivity of the law; the independence of the judiciary. Professor Yan Cunsheng of Northwest University of Politics and Law believes that there are six principles of rule of law that should be emphasized and re-understood in our country: the principle of taking law as the criterion; feasibility principle; principle of universality; principle of naturalness; the principles of natural justice. 15 From the practice of rule of law in contemporary China, I think we should define the principles of the rule of law are as follows: the law should have the supremacy; the law should be universality and consistency; the law should be open, transparent and predictable; all people are equal before the law; judiciary authorities exercise their functions and powers according to law; abide by legal procedures. 


\section{RULE OF LAW AND SPIRIT OF CONTRACT}

We have argued that the source of the spirit of the west rule of law is the spirit of rule of law of ancient Greek, the legal heritage of Romans and the theological tradition of monotheism, however, all of them have extremely strong contract consciousness. In the west, contract culture can be traced back to the secular source of the ancient Greek civilization and the religious origins of Christian, and its development history has experienced several different stages, such as ancient Rome, Middle Ages, and modern times. Some Chinese scholars believe that the contract in the Western cultural tradition has four meanings: the first is the contract in economic and legal concept of Roman law; the second is the contract in religious theology concept of Bible; the third is the contract of the social politics concept in the works of antityrant theorists in the late mediaeval period and Hobbes, Locke and Rousseau, and the more early development history can be seen from the ideologists of Ancient Greece and Rome; the fourth is the contract as the moral philosophy concept, which is shown in Rawls, but Kant is the pioneer.16 As a kind of idea, the contract not only exists in the private law field where the economy and politic associate with each other, but also lies in state politics and other public law field.17 The Chinese contract has a long history, and the written contract has a history with more than six thousand and five hundred years. 18 As a kind of transaction method, the contract originally appeared in the pre-Qin period, and the agreement of contract form was more widely used in the Western Han and Eastern Han Dynasties.19 In the period of Jin and Tang dynasties, the scope of contract was further expanded, and it even appeared in the "contract promulgated by feudal official" of official seal. After the Song and Yuan Dynasty, the form of contract gradually tended to be mature and standardized. The form and content of the contract in Ming and Qing Dynasty have entered into the period of standardization.20 During the planed economy after the founding of the people's Republic of China, the contract was replaced by an agreement by piece. After Third Plenary Session of the 11th Central Committee of the Chinese Communist Party, large-scale legislation was carried out, and the contract law entered the stage of substantive development. Historically, Chinese contract has not experienced the same development as the west in the five thousand civilization history of China, from religious ideas to the mundane life. The contract phenomenon only exists in the extremely limited private law area, and there are no social contract idea in the sense of western politics and ethical norms in the national political life and public law norms. The contract always stays in the surface, and does not form the contract idea and contract culture as the western countries, and even not deepen them; therefore, the foundation of the spirit of rule of law is out of the question.

\section{CONCLUSION}

The spirit of rule of law of ancient Greek, the legal heritage of Romans and the theological tradition of monotheism have not been rooted in China, however, the counterparts are the monarchical power that "subjects must obey their emperor absolutely even if he orders them to die", the traditional Confucian ethics that "ruler guides subject, father guides son and husband guides wife", and the strict hierarchy that "respecting for seniority and hierarchy there". We even can affirm that if the Opium War in 1840 did not knock on the doors of old Oriental Empires, the current Chinese land still would not appear the buds of "rule of law", and we still live in the nights of "rule of man". No matter how we argue, the modern "rule by law" belongs to the foreign goods for us, but we can not ignore the historical inertia. The inertia is reflected in the political, cultural and social aspects, and our consciousness and behavior will be more or less governed by this kind of historical inertia. For example, on September 20, 1954, the first meeting of the first session of the National People's Congress passed unanimously Constitution of the People's Republic of China, and the Article LXXXV stipulated that "the citizens of People's Republic of China are equal in law". However, in the Anti-Rightist Movement in 1957, the mental attack and even physical cruelty for the "rightists" doubtlessly violated the spirit that "the citizens of People's Republic of China are equal in law" in the Constitution in 1954; moreover, in the 10-year cultural revolution which broke out in 1966, the Constitution became a mere scrap of paper, and the fundamental rights of ordinary citizens, even the president of the state, could not be guaranteed, and the whole society was in the anarchy of production; it was the rude infringement of historical inertia of rule of man with more than two thousand years on the "rule of law", which has just started in the new China. It is worth mentioning that the second Constitution of the People's Republic of China adopted by the first meeting of the Fourth National People's Congress in 1975 deleted the principle that all people are equal before the law in the Constitution of 1954, moreover, the first meeting of the Fifth National People's Congress in the early 1978 passed the third Constitution of new China to inherit the Constitution of 1975, and there was no relative statement that "the citizens of People's Republic of China are equal in law".

However, the reform and opening-up policy starting at the end of 1978 exerted infinite external force on this kind of historical inertia. The openness of social environment, easing international situation and the initial establishment of socialist market economy provided with good atmosphere for the legal construction of new China. The new environment appealed to the reform for governing conceptions, which was not only the deep introspection for the concept of unsound "rule of law" and the enormous damage caused by rule of man on nationbuilding, but also the intrinsic requirements of continuous construction of the socialist market economy. It is generally acknowledged that market economy is characterized by equality, competitiveness, rule of law and openness, and it is an effective mechanism to adapt to social production and promote the development of the whole economy and society. As a rule of conduct to maintain national and social stability, the law has existed in the form of natural economy, feudal economy and planned economy. In general, in market economy conditions, law system with characteristics of rule of law has been formed. 21

Under the bold changes that the planned economy of single public ownership structure is transformed into the socialist market economy that public ownership plays a dominant role and different economic sectors develop side by side, the 
concept of "rule of law" of "law-based governance" is almost certain. On December 13, 1978, when Deng Xiaoping presided over the closing session of the Central Working Conference, he pointed out that "the current problem is that the law is incomplete. We should concentrate our efforts on making criminal law, civil law, litigation law and other necessary laws, and these laws should be discussed and adopted by a certain democratic process. We should also strengthen the procuratorial organs and judiciary authorities to do well that there must be laws to go by, the laws must be observed and strictly enforced, and law-breakers must be prosecuted." The 16-Word Principle (in Chinese characters) that "there must be laws to go by, the laws must be observed and strictly enforced, and law-breakers must be prosecuted" became the basic requirements to establish the socialist rule of law. On April, 15, 1979, when Deng Xiaoping met Professor Li Zhengdao, a Chinese American, and his wife, he pointed out that it should carry forward democracy, however, the democracy needed discipline and rule of law, and both they were indispensable, and democracy and rule of law was unified. In June of 1981, the Sixth Plenary Session of its Eleventh Central Committee passed Resolutions to Certain Historic Issues about CPC Since Founding of New China and explicitly pointed out the major principle that "the Party must act within the scope of the constitution and the law." Subsequently, the Twelfth National Party Congress wrote it into the general principles of new Party Constitution, meanwhile, recorded it into the preface and general principles of new constitution passed in 1982. In September of 1989, Jiang Zemin seriously declared at Chinese and foreign news conference that "we should definitely not substitute the politics by the party and substitute the law by the party. This is also the question of the rule of man or rule of law in the press circles, and I think we must follow the principle of the rule of law." In September of 1997, on the basis of scientifically summarizing the experience and lessons of the construction of socialist democracy and legal system in China, the Fifteen National Party Congress seriously put forward that the major strategic mission that "governing the country according to law and building a socialist country under the rule of law". In 1999, the constitutional amendment passed by the Second Session of the Ninth National People's Congress stipulated that "the People's Republic of China implements rule by law and establishes socialist rule of law country". "Rule by law" was written into the constitution for the first time and fundamentally affirmed the strategy of running a state of "rule of law" in China. The Eighteenth National Congress of CPC proposed the new target for construction of government ruled by law that "the basic strategy of rule by law will be implemented fully, the law-based government will be basically established, the public credibility of the judiciary will be enhanced constantly and the human rights will be respected and guaranteed actually in 2020." The construction of rule of law had been mentioned more than hundred times in Hu's report at 18th Party Congress, which never appeared at any previous meeting of the party. The degree of recognition of the party and the state for the construction of the rule of law in China could be seen. The Third Plenary Session of the Eighteenth National Congress of CPC put forward that "the fundamental solution to keeping power under control is to put power, government operations and personnel management under institutional checks to ensure that the people oversee the exercise of power and that power is exercised in a transparent manner." Moreover, the meeting made precise arrangements on how to achieve the construction of rule of law from each system. In October, 2014, the Fourth Plenary Session of 18th Central Committee of CPC held a seminar for the problems of rule by law for the first time. On October 28, Decision of the CPC Central Committee on Major Issues Pertaining to Comprehensively Promoting the Rule of Law issued.

We can see that the policy of running a state of "rule by law" is proposed by the Communist Party of China on the plenary session and is written into the constitution by the Ninth National People's Congress, and then the policy becomes the will of state, which means that any individual, organization and party within the territory of the People's Republic of China can not violate the law. The law of China is no longer just a tool to restrict part of people and class, and no individual, organization or party can be above the law, which is consistent with the basic principle of "the supremacy of law" in the concept of contemporary rule of law. Moreover, the process is procedural fair, transparent and consistent with the legislative principles stipulated by the constitution of China. However, Article XXXIII in Chapter II that the fundamental rights and duties of citizens of the current Constitution of the People's Republic of China passed by the First Session of the Seventh National People's Congress in 1982 explicitly stipulates that all people with the nationality of People's Republic of China are citizens of People's Republic of China. The citizens of People's Republic of China are equal before the law. The state respects and guarantees human rights. Therefore, we can say that "rule by law" is the expression of "the rule of law" in China. The People's Republic of China is a country under the rule of law. Some people doubt about whether China is a country governed by rule of law, and they actually are questioning the constitution of People's Republic of China, which is fundamentally contradictory.

\section{REFERENCES}

[1] Liu Zuoxiang, editor-in-chief: Jurisprudence, edition 2005, Social Science Academic Press (China), Page 1.

[2] Wang Renbo: the third article of The Chineseness of Law, One Legal Concept of the Lowest Limit, Page 117.

[3] Qian Hongyou: The Spirit of the Rule of Law in the West and the Way of the Rule of Law in China, Peking University Law Journal, Issue 6, 1995, Page 24.

[4] Xia Yong: Origins and Development of the Rule of Law, edition 2004, China Social Sciences Press, Page 3 and 4.

[5] Li Buyuan: Fayuan Spring and Autumn, edition 2007, China Legal Publishing House, Page 10 and 48.

[6] Xia Yong: Origins and Development of the Rule of Law, edition 2004, China Social Sciences Press, Page 6 and 7

[7] Gao Zhenqiang, Meng dekai: Essentials of the Spirit of Rule of Law, edition 2013, Law Press China, Page 25

[8] Aristotle: Politics, Beijing. The Commercial Press, 1997.

[9] Li Deshun: The Spirit of the Rule of Law Should Be A Belief, published in Member of the Communist Party, Issue 13, 2012, Page 40.

[10] Li Buyuan: Promoting the Rule by Law Needs to Deepen the Understanding for the Spirit of the Rule of Law, published in Legal Daily, the third edition, August 31, 2007. 
[11] Zhang Wenxian: Promote the Spirit of the Rule of Law, published in Legal Daily, August 17, 2007; Zhang Wenxian: General Theory of Legal Philosophy, Liaoning People's publishing house, edition 2009, Page 406.

[12] Li Lin: Greatly Promote the Spirit of Rule of Law of "Good Law and Governance", published in Legal Daily, August 31, 2007.

[13] Hao Yaowu, Sun Changchun: On Rule of Law Spirit in Modern China, published in Public Administration \& Law, Issue 9, 2009, Page 29-31.

[14] Gao Zhenqiang: Discussion on the Logic Connotation and Denotation of the Spirit of the Rule of Law, published in Guizhou Social Sciences, May, 2009, Page 83.

[15] Yan Cunsheng: Discussion on the Principle of Rule of Law and the Practice of the Rule of Law in China, published in Journal of Gansu Institute of Political Science and Law, Issue 1, 1999.

[16] He Huaihong: Contract Ethics and Social Justice-- The History and Reason of Rawls's Theory of Justice[M]. Beijing: China Renmin University Press, 1993: 10-39.

[17] You Chunyuan: Contract Civilization and Construction of Government by Laws in the View of Socialist Market Economy, doctoral thesis, Nanjing University of Aeronautics and Astronautics, 2012.

[18] Li Zhongsheng. China's Legal System (Volume 2)[M]. Taiwan Huaxing Cultural Undertakings Center. 1985:349.

[19] Gao Heng. Debt Document Edition and Proof in Bamboo Slips of Han Dynasty. Han Yanlong compiles, Historical Comments Compilations of Law (Volume 3)[C]. Beijing: Law Press China, 2000:140-141.

[20] Li Zhuhuan. The Study of Chinese Traditional Civil Contract. Han Yanlong compiles, Historical Comments Compilations of Law (Volume 2)[C]. Beijing: Law Press China, 1999:69-100.

[21] Wei Xinghua: The Socialist Market Economy and the Rule of Law, Economic Research Journal, Issue 01, 2015, Page 10. 